\title{
PESANTREN VIRTUAL: DINAMISASI ATAU DISRUPSI PESANTREN?
}

\author{
Hatta Fakhrurrozi \\ hatta@iainpalu.ac.id \\ FTIK IAIN Palu
}

\section{Abstract}

The industrial revolution that penetrated the world of education forced Islamic boarding schools (Pesantren), as part of education, to mutate in new form to find the ideal format as an adaptive step to keep up to date. Pesantren which have a cultural base of traditional society make various efforts to make acculturation with technology. The efforts of these pesantren can be seen from the number of pesantren websites, which provide information about pesantren and religious programs online. On the other hand, virtual pesantren have also emerged, which do not have a real pesantren institutional base in the community, using online media as an operational base. Some of these virtual Islamic boarding schools have strong buildings in cyberspace, with a wider reach than Islamic boarding schools. Its flexible and open nature makes virtual pesantren have their own community in cyberspace. Furthermore, problems arise when virtual Islamic boarding schools intersect with conventional Pesantren in cyberspace. This research is a library research that uses printed and online media as data sources. This study aims to find differences in the characteristics of virtual pesantren, and their relationship with the dynamics of pesantren in the era 4.0. From the content analysis conducted at several virtual pesantren, it was found that some of them used the same name as real pesantren, thus creating ambiguity of virtual pesantren.

Keywords: Virtual Pesantren, industrial revolution 4.0, pesantren disruptions, dynamic pesantren

\footnotetext{
Abstrak

Geliat revolusi industri yang merambah dunia pendidikan memaksa Pesantren, sebagai bagian dari pendidikan, untuk bermutasi menemukan format ideal sebagai langkah adaptif mengikuti perkembangan zaman. Pesantren yang memiliki basis kultur masyarakat tradisional melakukan berbagai upaya sebagai
} 
bentuk akulturasi dengan teknologi. Upaya pesantren tersebut dapat dilihat dari banyaknya website pesantren, yang memberikan informasi tentang pesantren dan program keagamaan secara online. Di sisi lain, bermunculan juga pesantren virtual, yang tidak memiliki basis kelembagaan pesantren secara riil di tengah masyarakat, dengan menggunakan media online sebagai basis operasional. Beberapa pesantren virtual tersebut memiliki bangunan kokoh di dunia maya, dengan jangkauan lebih luas daripada lembaga pesantren. Sifatnya yang fleksible dan terbuka membuat pesantren virtual memiliki komunitas tersendiri di dunia maya. Selanjutnya, permasalahan muncul ketika pesantren virtual bersinggungan dengan pesantren konvensional di dunia maya. Penelitian ini merupakan library research yang menggunakan media cetak dan online sebagai sumber data. Penelitian ini bertujuan untuk menemukan perbedaan karakteristik pesantren virtual, dan keterkaitannya dengan dinamika pesantren pada era 4.0. Dari analisis konten yang dilakukan pada beberapa pesantren virtual ditemukan bahwa beberapa diantara mereka menggunakan nama yang sama dengan pesantren riil, sehingga menumbulkan ambiguitas dalam pemaknaan pesantren virtual.

Kata kunci: Pesantren virtual, revolusi industry 4.0, disrupsi pesantren, dinamika pesantren

\section{PENDAHULUAN}

Perkembangan ilmu pengetahuan dan teknologi yang begitu cepat telah mengantarkan kehidupan manusia pada masa Revolusi Industri 4.0, sebuah era yang ditandai dengan integrasi teknologi informasi dan komunikasi, dengan internet sebagai simbol Utama perubahan. Revolusi Industri 4.0 merupakan sebuah lompatan besar di sektor industri yang mempengaruhi berbagai aspek kehidupan masyarakat. Aspek sosial, politik, budaya, ekonomi, pendidikan, reliji, dan aspek kehidupan lainnya 'dipaksa' untuk beradaptasi dengan perkembangan teknologi tersebut. Pada aspek pendidikan, lembaga pendidikan saat ini berupaya melakukan integrasi dengan teknologi telekomunikasi dalam praktik pembelajaran di sekolah. Hal yang sama juga 
dilakukan oleh Pesantren, sebuah lembaga yang selama ini dikenal sebagai lembaga pendidikan tradisional.

Maraknya persebaran ilmu pengetahuan melalui media internet, dengan berbagai varian software pendukung, menyebabkan sebaran informasi secara massif di tengah masyarakat. Persebaran ini semakin tidak terbendung karena didukung dengan kemudahan akses internet via perangkat mobile. Asosiasi Penyelenggara Jasa Internet Indonesia (APJII) telah melalukan survei mengenai penetrasi internet dan perilaku pengguna internet di Indonesia. Hasil survei tersebut mengungkapkan bahwa pengguna internet di Indonesia mencapai 171,17 juta. Ini berarti jumlah pengguna internet sebesar $64,8 \%$ dari total penduduk Indonesia ${ }^{1}$. Angka pengguna internet terus bertambah, dan pada juni tahun 2020 pengguna internet diperkirakan sudah mencapai 196,7 juta jiwa ${ }^{2}$. Sebuah fenomena yang cukup untuk menguatkan sebuah hipotesa bahwa masyarakat Indonesia, secara makro, sudah siap menghadapi era revolusi industry 4.0 .

Geliat revolusi industri juga merambah dunia pendidikan, tidak terkecuali pesantren. Pesantren yang memiliki basis kultur masyarakat tradisional seperti pesantren Sidogiri, pesantren lirboyo, pesantren Tebuireng, Pesantren Darul Ulum, dan pesantren salaf lainnya melakukan berbagai upaya sebagai bentuk akulturasi dengan teknologi. Upaya pesantren tersebut dapat

${ }^{1}$ Seperti dikutip Nita Siti Mudawamah, "Perilaku Pengguna Internet: Studi Kasus Pada Mahasiswa Jurusan Perpustakaan dan Ilmu Informasi UIN Maulana Malik Ibrahim", dalam BIBLIOTIKA: Jurnal Kajian Perpustakaan dan Informasi Volume 4 Nomor 1, 2020, h. 108. http://journal2.um.ac.id/index.php/bibliotika.

2 Angka ini dilansir oleh kominfo berdasarkan pada keterangan Sekjen APJII (Asosiasi Pengguna Jasa Internet Indonesia), yang menyatakan "jika digabungkan dengan angka dari proyeksi Badan Pusat Statistik (BPS) maka populasi Indonesia tahun 2019 berjumah 266.911.900 juta, sehingga pengguna internet Indonesia diperkirakan sebanyak 196,7 juta pengguna". Lihat https://www.kominfo.go.id/content/detail/30653/dirjen-ppi-surveipenetrasi-pengguna-internet-di-indonesia-bagian-penting-dari-transformasidigital/0/berita_satker, diakses 02 April 2021. 
dilihat dari banyaknya website pesantren, yang memberikan informasi tentang pesantren secara online. Pesantren berkolaborasi dengan internet tidak hanya pada aspek sosialisasi atau manajemen pemasaran saja, tetapi juga pada aspek pembelajaran. Di sisi lain, pesantren-pesantren tersebut tetap beroperasi secara nyata di masyarakat melalui lembaga pendidikan yang sudah berdiri sejak sebelum masa revolusi 4.0.

Pada perkembangan selanjutnya, epistemologi pesantren direduksi dengan munculnya istilah pesantren virtual atau pesantren online. Berbeda dengan konsep pesantren yang sudah mapan pada saat ini, pesantren virtual mengurangi beberapa aspek yang sudah lazim terdapat dalam sebuah pesantren. Keberadaan Masjid, pemondokan/asrama dan Kyai sudah tidak menjadi persyaratan dalam pesantren virtual. Salah satu aspek yang memiliki kesamaan antara pesantren virtual dan pesantren non virtual terletak pada materi pelajaran dan santri/peserta didik, meskipun sebagian peneliti masih meragukan konsep santri dalam pesantren virtual ${ }^{3}$. Pesantren virtual banyak bermunculan setelah keberhasilan fenomena fatwa online yang berkembang pada akhir 2000an.

\footnotetext{
${ }^{3}$ Salah satu contoh adalah Saifuddin Zuhri Qudsy. Qudsy menyoroti situasi pembelajaran pada pesantren virtual yang seringkali Kyai/Ustads/ustadzah menggunakan nama anonym dalam bentuk tim guru, tim asatidz, atau dewan Asatidz. Qudsy mempertanyakan siapa yang memegang otoritas ajaran di pesantren virtual. "Siapa yang akan memegang otoritas untuk menentukan postingan mana yang baik dan mana yang picik, jika semuanya anonim? Tentu hal ini akan membuat si pengguna internet berada dalam 'ruangan'-nya sendiri yang memberinya kekuasaan untuk menjadi santri dan kyai dalam waktu yang bersamaan. la menjadi santri karena ia yang sedang mencari ilmu agama, namun ia juga menjadi kiai (untuk dirinya sendiri) karena ia yang memutuskan ajaran mana yang akan ia gunakan: momen inilah yang disebut sebagai e Death of the Author (matinya sang pengarang). Oleh karenanya dibutuhkan kedewasaan dan kematangan pola pikir dan sikap dalam menyaring dan menggunakan informasi yang didapat di internet, terlebih jika informasi itu terkait dengan agama". Lihat Saifuddin Zuhri Qudsy, "Pesantren Online: Pergeseran Otoritas Keagamaan di Dunia Maya", dalam Living Islam: Journal of Islamic Discourses, Volume II Nomor 2, November 2019.
} 
Pergeseran paradigm pesantren akan terus berlanjut seiring dengan laju perkembangan teknologi. Pesantren virtual akan bermutasi menemukan bentuk ideal seiring perjalanan waktu. Begitu juga sebaliknya, pesantren non virtual juga akan bermutasi menemukan format terbaik sebagai jawaban atas perkembangan teknologi dan informasi. Kedua mutasi tersebut bermuara pada need and demand masyarakat. Dan jika merujuk pada perubahan tatanan pada masyarakat era 4.0, tidak menutup kemungkinan pesantren akan mengalami disrupsi, sama seperti disrupsi ekonomi yang dialami oleh perusahaan-perusahan besar dunia $^{4}$. Pada konteks ini, diperlukan tinjauan analisis terkait dengan faktor determinan pesantren virtual dan non virtual, yang pada akhirnya memperjelas status kedua obyek tersebut.

Penelitian ini merupakan library research, dengan mengunakan data-data dari media cetak dan online sebagai sumber data. Artikel ini berusaha mengkaji format pesantren virtual yang beredar di internet dan melakukan beberapa perbandingan dengan pesantren tradisional (non virtual) yang selama ini sudah berkembang di tengah masyarakat. Tujuan penelitian ini untuk menemukan dinamika pesantren pada era revolusi industri 4.0. Pengunaan kata pesantren virtual dalam tulisan ini tidak merujuk pada website www.pesantrenvirtual.com, tetapi lebih dimaksudkan merujuk pesantren yang beroperasi secara online.

${ }^{4}$ Era disrupsi sudah banyak memengaruhi berbagai sektor bisnis. Penyewaan film ternama seperti Blockbuster, mengalami kebangkrutan dan terpaksa menutup 129 gerainya pada awal 2013 setelah kalah bersaing dengan Netflix dan iTunes. Raksasa penyewaan buku, Barnes \& Noble juga kewalahan menghadapi persaingan dengan toko buku online seperti Amazon.com. Terlebih, maraknya website-website digital yang menyediakan file buku berbentuk PDF dan ebook turut memengaruhi perubahan dalam sektor bisnis tersebut. Artikel ini telah tayang di Kompas.com dengan judul "Tips-tips agar Siap Menghadapi Era Disrupsi", https://biz.kompas.com/read/2020/03/11/230918328/tips-tips-agar-siapmenghadapi-era-disrupsi, diakses 02 April 2021. 


\section{PEMBAHASAN \\ Pesantren}

Secara kelembagaan, pesantren merupakan lembaga pendidikan tertua di Indonesia. Pesantren, dalam berbagai derivasinya, merupakan sebuah gerakan masyarakat muslim yang berupaya untuk mencerdaskan kehidupan bangsa melalui penyebaran ilmu yang berbasis agama. Mastuhu, menjelaskan bahwa pesantren merupakan lembaga pendidikan tradisional Islam yang bertujuan untuk memahami, menghayati dan mengamalkan ajaran Islam dengan menekankan pentingnya moral agama sebagai pedoman hidup bermasyarakat ${ }^{5}$. Pesantren, melalui sistem pendidikannya, memberikan kontribusi besar dalam perkembangan ilmu pengetahuan di Indonesia, di samping juga pada budaya dan pranata yang berkembang di masyarakat.

Secara etimologi, perkataan pesantren berasal dari akar kata santri dengan awalan "pe" dan akhiran "an" yang berarti tempat tingal santri'. Selain itu, Wahjoetomo berpendapat bahwa pesantren merupakan gabungan kata "sant" yang berarti manusia baik, dan "ira" yang berarti suka menolong, sehingga kata pesantren dapat berarti tempat pendidikan manusia baik-baik ${ }^{7}$. Di luar pulau Jawa, lembaga pendidikan pesantren ini disebut dengan nama lain seperti Surau di Sumatera Barat, Rangkang dari Dayah di Aceh dan Pondok di daerah lain ${ }^{8}$. Secara historisitas, pesantren merupakan cikal bakal pendidikan Islam di Indonesia yang menelurkan berbagai macam corak dan pola pendidikan Islam yang saat ini ada, seperti madrasah salafiyah, madrasah diniyah, madrasah tsnawiyah, madrasah ibtidaiyyah, madrasah aliyah, ma'had 'aly, madrasah huffadz, dan madrasah lainnya

${ }^{5}$ Mastuhu, Dinamika Sistem Pesantren, (Jakarta: Sen INIS, 1994), h. 6.

6 Samsul Nizar, et.al. Sejarah Sosial dan Dinamika Intelektual Pendidikan Islam di Nusantara, (Jakarta: Kencana Prenada Media Group, 2013), h. 87.

7 Wahjoetomo, Perguruan Tinggi Pesantren, (Jakarta: Gema Insani Press, 1997), h. 5.

${ }^{8}$ Nizar, et.al. Sejarah Sosial..., 87. 
dalam kemasan yang lain pula seperti majlis taklim, halaqah, majlis pengajian dan sebagainya pula ${ }^{9}$.

Sebagai sebuah lembaga pendidikan keagamaan, pesantren memiliki ciri dan kekhasan tersendiri dan berbeda bila dibandingkan dengan lembaga pendidikan lainnya. Hal ini dapat dilihat dari sistem pembelajaran yang dilaksanakan oleh pesantren, yang menghimpun komunitas tersendiri, di dalamnya hidup bersama-sama sejumlah orang yang dengan komitmen keikhlasan dan kerelaan hati, mengikat diri dengan Kiai, Tuan guru, Ajengan atau nama lainnya, untuk hidup bersama dengan standar moral tertentu, dalam membentuk kultur atau budaya tersendiri ${ }^{10}$. Dalam kalimat lain, Syafi'I Noer mengemukanan bahwa pesantren merupakan tempat penampungan sederhana bagi pelajar yang jauh dari negeri asalnya, dan merupakan tempat tinggal kiai bersama santrinya yang bekerja sama untu memenuhi kebutuhan hidup sehari-hari. Pesantren juga berfungsi sebagai tempat training atau latihan bagi santri agar mampu hidup mandiri dalam masyarakat ${ }^{11}$.

Ciri khas lain pesantren adalah adanya hubungan Ngawulo antara santri dengan kiai. Santri secara sukarela mengabdikan diri kepada kiai dalam berbagai aktivitas keseharian di pesantren. Keinginan santri seperti ini biasaranya didorong oleh rasa ingin mendapatkan berkah (ngalap berkah) dari kiai. Dalam konteks ini, santri berusaha semaksimal mungkin melaksanakan segala hal yang diperintahkan kiai, dan bahkan juga pada hal yang tidak diperintahkan kiai dengan tujuan untuk menyenangkah hati kiai. Semua dilakukan dengan penuh keikhlasan dan ketawadluan. Relasi humanis antara kiai dan santri ini secara tidak langsung membentuk karakter dan

${ }^{9}$ Azyumardi Azra, Pendidikan Islam Tradisi dan Modernisasi Menuju Millenium Baru, (Jakarta: Logos Ilmu Wacana, 1996), h. 71.

10 Ahmad Syafi'I Noer, "Pesantren Asal Usul dan Pertumbuhan Kelembagaan", dalam Abudin Nata (ed), Sejarah Pertumbuhan dan Perkembangan Lembaga-lembaga Pendidikan Islam di Indonesia, (Jakarta: PT. Grasindo, 2001), h. 89-90.

11 Ibid. 
kepribadian santri ketika berada di pesantren, terutama dalam hal menjaga sikap dan perbuatan baik kepada orang lain, menghargai dan menghormati orang lain, tidak memandang rendah dan melayani sesama, menghormati yang lebih tua, kepatuhan dan kedisiplinan dan lemah lembut dalam bertutur kata. Sikap dan karakter tersebut biasanya terbawa sampai pada saat mereka lulus dari pesantren dan kembali ke masyarakat.

Metode pembelajaran mengunakan sorogan, bandongan dan wetonan juga menjadi ciri khas pesantren. Metode ini biasanya digunakan dalam pembelajaran kitab-kitab kuning yang digunakan di Pesantren. Kiai dan santri duduk sama rendah dalam sebuah ruangan, dan para santri mendengarkan penjelasan dari kiai tentang kitab yang dikaji. Pada metode sorogan, satu per satu santri menghadap kiai untuk mengkaji, menerjemah, setor hafalan atau mentashih bacaan kitab tertentu. Pendampingan secara langsung yang dilakukan oleh kiai sangat bermanfaat dalam menciptakan iklim intelektual di pesantren dan dapat menambah semangat belajar para santri.

Dari sisi manajemen, Sudah menjadi pandangan umum bahwa pesantren lekat dengan figur kyai sebagai figur sentral, otoritatif dan pusat seluruh kebijakan dan perubahan. Pertama, kepemimpinan yang tersentralisasi pada individu yang bersandar pada kharisma serta hubungan yang bersifat paternalistik. Kebanyakan pesantren menganut pola serba mono, yaitu monomanajemen dan mono-administrasi, sehingga tidak ada delegasi kewenangan ke unit kerja yang ada dalam organisasi. Kedua, kepemilikan pesantren bersifat individual atau keluarga, bukan komunal. Otoritas individu kyai sebagai pendiri sekaligus pengasuh pesantren sangat besar dan tidak bisa diganggu gugat. Faktor nasab atau keturunan juga kuat sehingga kyai bisa mewariskan kepemimpinan pesantren kepada putranya yang dipercaya tanpa ada komponenen pesantren yang berani memprotes $^{12}$.

12 Endang Turmudi, Perselingkuhan Kiai dan Kekuasaan, (Yogyakarta: LkiS, 2004), h. 35. 
Realitas saat ini menunjukkan bahwa lembaga pesantren telah berkembang secara variatif baik dari isi (kurikulum) maupun bentuk (manajemen) serta struktur organisasinya. Sejalan dengan penyelenggaraan pendidikan formal, beberapa pesantren mengalami perkembangan pada aspek manajemen, organisasi dan administrasi pengelolaan keuangan. Perkembangan ini dimulai dari perubahan gaya kepemimpinan pesantren dari kharismatik ke rasionalistik, dari otoriter paternalistik ke diplomatic partisipatif, atau dari laissez faire ke demokratik $^{13}$.

\section{Pesantren Virtual}

Kelahiran pesantren virtual atau pesantren online beriringan dengan keterbukaan akses informasi dan telekomunikasi. Perkembangan teknologi dan peningkatan mobilitas masyarakat tampaknya menjadi alasan utama atas muncul dan berkembangnya pesantren virtual. Dengan berbasis pada jaringan online, kehadiran Pesantren Virtual mendapat sambutan yang baik dalam masyarakat. Hal ini setidaknya terlihat dari semakin meningkatnya animo masayarakat untuk mengakses berbagai informasi yang diberikan. Dengan memiliki 'wajah baru' berupa website, pola interaksi yang dibangunpun turut serta berubah, website Pesantren Virtual membuka ruang bagi para pengunjung website untuk turut beperan aktif dengan mengirimkan tulisan atau berbagai hasil pemikiran dan bahkan pertanyaan ke dalam website, hal mana yang tampaknya membuat banyak orang kemudian merasa menjadi 'bagian penting' dari tumbuh dan berkembangnya Pesantren Virtual secara umum ${ }^{14}$.

Keberadaan internet merupakan produk kemajuan zaman yang mana bisa dipergunakan sebagai salah satu alternatif cara berdakwah dan dimungkinkan terciptanya komunikasi yang lebih

13 Sulthon Masyhud, dkk. Manajemen Pondok Pesantren, (Jakarta: Diva Pustaka, 2003), h. 15.

14 Saifuddin Zuhri Qudsy, "Pesantren Online: Pergeseran Otoritas Keagamaan di Dunia Maya", dalam Living Islam: Journal of Islamic Discourses, Volume II Nomor 2, November 2019. 
baik antar umat yang semakin menglobal ini. Sebagian orang muslim mengakui manakala dakwah dilakukan melalui media maya, daya jangkau penyiaran Islam akan lebih efektif, baik dalam segi waktu, jarak maupun ruang. Penyiaran dakwah melalui media ini nantinya akan menjadi titik tolak untuk menemukan bentuk ideal suatu sarana dakwah yang lebih tepat untuk dikembangkan di masa kinidan masa depan. Keberadaan internet yang sangat tinggi nilai kegunaannya ini tentu akan memiliki nilai tersendiri manakala dimanfaatkan dalam kegiatan dakwah dengan strategi manajemen yang lebih mampu menjangkau mad'u (penerima dakwah) yang lebih luas ${ }^{15}$.

Beberapa contoh pesantren virtual seperti https://pesantrenalmadinah.com/, https://www.pesantrenvirtual.com/, http://www.pesantrenvirtual.net, https://daaruttauhiidvirtual.com/ merupakan pesantren virtual yang memiliki bangunan kokoh di dunia maya. Pesantren online tersebut tidak memiliki kelembagaan dalam dunia nyata dan hanya beroperasi di dunia maya. Beberapa diantara pesantren online tersebut mengaku memiliki kantor di beberapa kota besar di Indonesia, dan berafiliasi dengan pesantren-pesantren yang ada di Indonesia maupun manca negara. Nama website pesantren virtual yang bermacan-macam memberikan nuansa kebebesan public yang tidak terbatas. Beberapa nama pesantren virtual mengarah pada pesantren riil yang ada di tengah masyarakat, tetapi banyak juga yang tidak memiliki pesantren riil.

Dalam sisi manajemen, Pesantren Virtual dikelola dengan model manajemen yang modern, dalam arti bahwa segalanya dilakukan secara virtual. Meski demikian, alur komunikasi dan tugas ditata rapi sedemikian rupa. Manejeman Pesantren Virtual meliputi bagian redaksi, pengajar, editor, tim web, pelaksana dan penanggung jawab harian. Namun yang unik dari Pesantren Virtual adalah segala sesuatunya yang dilakukan serba virtual.

\footnotetext{
${ }^{15}$ Akhmad Rifa'i, "E-Dakwah dalam Pesantren Virtual”, dalam Millah Vol. IX, No. 1, Agustus 2009
} 
Pola interaksi, hingga manajerial kelembagaan, seluruhnya dilakukan dalam dunia maya. Hal ini menyebabkan banyak santri mereka yang tidak tahu menahu perihal ustaz-ustaz yang selama ini menjadi rekan belajarnya, bukan itu saja, beberapa pengurus PV juga belum pernah bertemu atau mengenal sama sekali. Kini dalam beberapa tahun ini, semenjak adanya teknologi Whatsapp dan Telegram, PV mulai fokus konsen dengan konsultasi agama secara online ${ }^{16}$.

Beberapa ciri khas pesantren virtual, diantaranya: 1) bersifat online, menggunakan media internet sebagai sarana utama komunikasi warga pesantren virtual, 2) Santri dan guru tidak bertatap muka langsung, komunikasi menggunakan teknologi kekinian seperti website, teleconference, mailing list, chatroom di WA, fanspage FB dan telegram, classroom, zoom, dan aplikasi sosial lainnya, 3) tidak terdapat jenjang pendidikan, yang ada hanya jenjang materi pendidikan. Kelulusan ditentukan jika sudah menuntaskan materi tertentu. 4) tidak ada batasan umur untuk pembelajaran ilmu keislaman, dari berbagai kalangan dan latar belakang pekerjaan. Lingkupnya dalam negeri maupun di luar negeri. 5) materi pelajaran bebas pilih. Pada pesantren virtual secara umum santri bebas memilih mata pelajaran atau kitab yang mau dipelajari, kecuali pada pesantren virtual yang berisi kajian tematik. Selain itu, santri juga dapat memilih berapa lama proses belajar di pesantren. Santri bebas menentukan apa yang dia inginkan, jika peserta didik tidak menemukan materi yang dicari, dia dapat mencari di pesantren virtual yang lain. Hal ini dapat dilakukan dengan cara surfing internet dan bersantai di rumah, tanpa harus bergerak keluar rumah. Beberepa Beberapa hal tersebut pada akhirnya menjadi ciri khas pesantren virtual.

Dari penjelasan diatas, maka dapat diuraikan beberapa hal terkait dengan kelebihan dari pesantren virtual. Pertama, keluasan jangkauan. Pesantren virtual berbasis internet yang

16 Saifuddin Zuhri Qudsy, "Pesantren Online: Pergeseran Otoritas Keagamaan di Dunia Maya", dalam Living Islam: Journal of Islamic Discourses, Volume II Nomor 2, November 2019. 
menghubungkan penduduk bumi tanpa ada batasan greografis. Ia dapat menjangkau semua tempat yang memiliki jaringan internet. Olehnya, pesantren virtual dapat menjangkau tempat/daerah yang terpencilpun sepanjang terdapat jaringan internet. Maka peserta didiknya dimungkinkan berasal dari berbagai suku bangsa dan negara, dan tidak mengherankan jika santri pesantren virtual berasal dari negara lain. Kedua, kemudahan akses. Peserta didik dapat mengikuti pembelajaran di pesantren virtual dari rumah, sambil bersantai atau duduk minum kopi, sambil berbaring atau sambil melakukan aktivitas lainnya. Pembelajaran dapat diakses menggunakan smartphone atau computer/laptop dimana saja, tanpa harus datang dan berdiam diri di kelas atau di ruangan tertentu tempat pembelajaran. Ketiga, menambah skill berbahasa. Komunikasi merupakan aspek penting dalam pesantren virtual. Komunikasi dilakukan secara virtual melalui berbagai macam aplikasi sosial. Komunikasi antar peserta dari negara berbeda menimbulkan proses belajar Bahasa antar sesama peserta didik. Diskusi

Berdasarkan penjelasan diatas, membandingkan pesantren konvensional dengan pesantren virtual menurut hemat penulis kurang tepat dilakukan, dengan alasan ketidaksamaan obyek yang dibandingkan. Terdapat banyak perbedaan seperti pada aspek sistem pendidikan, interaksi dan pergaulan antar santri, relasi guru/kiai dan santri, metode pembelajaran, dan terutama aspek sarana atau bangunan pada kedua model pesantren tersebut. Dua aspek yang dapat dibandingkan adalah aspek materi pelajaran dan buku atau kitab sebagai sumber belajar, dan santri sebagai peserta didik. tiga aspek lainnya, yang dikenal dengan arkanul ma'had seperti kiai, pondok/asrama, masjid tidak dapat dibandingkan karena tidak terdapat pada pesantren virtual. Sebaliknya, menyamakan kedua model pesantren tersebut juga merupakan langkah yang kurang tepat, karena perbedaan karakteristik yang telah dijelaskan diatas.

Pesantren virtual sebenarnya hanyalah sebuah konsep dakwah online dan pembelajaran online, sama seperti pembelajaran online lain yang sudah berkembang di masyarakat 
seperti kursus bahasa inggris online, kursus pemrograman online, kursus matematika online, pelatihan atau bimbingan karya ilmiah online dan program pembelajaran lainnya. Pesantren virtual dicirikan dengan kajian kitab-kitab keagaman atau materi keagamaan yang dilakukan secara online. Maka secara esensi, pesantren virtual merupakan kajian keagamaan virtual atau dapat dikatakan hanya sebatas dakwah online.

Pesantren virtual, menurut penulis, tidak akan dapat menggantikan sistem pendidikan yang ada di pesantren riil. Ditinjau dari aspek pembelajarannya, pembelajaran pada PV hanya sebatas pengembangan kognitif peserta didik. Pengembangan mental, psikomotorik dan spiritual hanya dilakukan melalui penambahan wawasan kepada peserta didik. Hal ini berbeda dengan pesantren yang memberikan pembelajaran pada aspek kognitif, afektif, psikomotorik dan spiritual dalam waktu yang bersamaan, dengan menggunakan metode terapan, saat peserta didik bermukim di pesantren. Pesantren tidak hanya mengajarkan santri tentang agama, tetapi juga tentang beragama, sebuah konsep yang sangat jauh pangang dari api pesantren virtual.

Secara kelembagaan, pesantren virtual belum diakui oleh pemerintah sebagai lembaga pendidikan resmi, berbeda dengan pesantren konvensional yang diakui legalitas kelembagaannya oleh pemerintah. Keberadaan pesantren virtual disamakan dengan website pembelajaran lain yang bertebaran di dunia maya. Namun tidak menutup kemungkinan, pesantren virtual akan bermutasi terus-menerus dalam sistem pendidikan sehingga pada akhirnya akan diakui secara resmi oleh pemerintah, khususnya pada legalitas ijazah.

Jargon pesantren virtual atau pesantren online yang tidak merujuk pada pesantren riil semestinya dihindari, meskipun secara ekonomis, jargon pesantren virtual memang sangat marketable. Pembaca akan langsung tertarik dengan istilah baru, yang selama ini hanya sebatas pesantren luring. Penamaan pesantren virtual, dengan nama sama dengan pesantren asli, merupakan ambiguitas yang membingungkan ketika pembaca 
ingin mengetahui website pesantren asli. Salah satu contoh adalah website pesantren daarut tauhiid milik aa' Gym. Setidaknya di internet terdapat empat website yang dikelola dengan sangat professional dengan menggunakan nama daarut tauhiid. Peneliti kemudian menghubungi pengelola website tersebut dan mendapatkan informasi ternyata hanya satu saja milik pesantren daarut tauhiiid, sedangkan tiga lainnya merupakan pesantren virtual yang tidak memiliki lembaga pendidikan secara resmi di dunia nyata. Hal seperti ini akan memunculkan kebingungan dalam masyarakat. Para pegiat pesantren virtual dapat mengganti nama dengan kajian online, mengaji online, dakwah online, dan semisal lainnya dengan menghindari penggunaan nama pesantren riil agar sasaran penjualan lebih tepat dan tidak ambigu. Contoh kongkritnya seperti ini, beberapa pesantren besar telah membuka diri di dunia maya seperti Pesantren Langitan dengan situsnya www.langitan.net, Pesantren Tebuireng melalui www.tebuireng.net, Pesantren Gontor dengan www.gontor.ac.id, Pesantren Sidogiri melalui www.sidogiri.net, dan pesantren lainnya. Situs-situs tersebut juga berisi kajian agama dengan berbagai materi yang berbeda, yang dapat juga dikategorikan sebagai pesantren online, namun situs tersebut merupakan situs resmi dari lembaga pesantren terkait. Sebuah permasalahan akan muncul ketika di internet terdapat situs $w w w . p e s a n t r e n s i d o g i r i . c o m$, atau www.pesantrentebuireng.net, atau lainnya yang memiliki kemiripan, padahal secara nama pesantren virtual tersebut tidak berafiliasi atau bahkan tidak berkaitan dengan pesantren yang asli. Kemiripan nama tersebut akan membingungkan pembaca online atau netizen, dan hal ini yang terjadi pada pesantren daarut tauhiid. Maka penamaan pesantren virtual, dengan nama pesantren tertentu, yang tidak merujuk pada kelembagaan resmi pesantren tersebut hendaknya dihindari agar tidak membingungkan masyrakat awam. Keterbukaan/transparansi tim manajemen Pesantren Virtual dalam memberikan keterangan pada website yang digunakan sangat penting, sebagai upaya penyebaran informasi yang 
akuntable kepada masyarakat. Hal tersebut hendaknya dilakukan dalam bentuk statemen yang jelas dan tertulis dalam website.

Munculnya Pesantren virtual diharapkan menjadi jawaban akan perlunya pengembangan sistem pendidikan pesantren di era digital dan informasi global saat ini tanpa ikut tenggelam dalam derasnya arus penyebaran informasi yang bebas nyaris tanpa batas. Pesantren virtual mencoba hadir sebagai bentuk keikutsertaan wadah pendidikan khususnya di bidang kajian keislaman dengan warna dan misi yang tidak berubah dari pondok pesantren konvensional yang ada.

\section{Kesimpulan}

Pesantren virtual merupakan sebuah bentuk dinamika pesantren pada era digital atau era revolusi industry 4.0. Keberadaan Pesantren Virtual memperkaya khazanah intelektual dan dakwah Islam. Dapat dikatakan disini, pesantren virtual merupakan hasil perkawinan silang antara pesantren dengan dunia digital, sebagai upaya adaptif pesantren terhadap revolusi industry 4.0. Pesantren digital bukan merupakan disrupsi pesantren, karena Pesantren Virtual tidak dapat menggantikan peran pesantren dalam kehidupan masyarakat. Peran pesantren yang sudah mengakar dan teruji selama ratusan tahun dalam kehidupan masyarakat memperkuat eksistensi, dan membuatnya kebal terhadap berbagai upaya disrupsi pesantren. Namun demikian, tidak dapat dipungkiri bahwa pergeseran paradigma pesantren konvensional menjadi pesantren virtual telah terjadi pada saat ini. Pengunaan nama pesantren riil pada pesantren virtual yang memunculkan ambiguitas dalam masyarakat, merupakan PR bagi tenaga IT pesantren karena dimungkinkan akan menjadi masalah ketika digunakan oleh pihak-pihak yang tidak bertanggung jawab. 


\section{REFERENCES}

Ahmad Syafi'I Noer, 2001. "Pesantren Asal Usul dan Pertumbuhan Kelembagaan", dalam Abudin Nata (ed), Sejarah Pertumbuhan dan Perkembangan Lembagalembaga Pendidikan Islam di Indonesia. Jakarta: PT. Grasindo.

Azra, Azyumardi. 1996. Pendidikan Islam Tradisi dan Modernisasi Menuju Millenium Baru, Jakarta: Logos Ilmu Wacana.

Fakhrurrozi, H. (2019). Standar Penilaian Aspek Psikomotorik Pendidikan Agama Islam. Paedagogia: Jurnal Pendidikan, 7(1), 155-170. https://doi.org/10.24239/pdg.Vol7.Iss1.37

https://www.kominfo.go.id/content/detail/30653/dirjen-ppisurvei-penetrasi-pengguna-internet-di-indonesia-bagianpenting-dari-transformasi-digital/0/berita_satker, diakses 02 April 2021.

Mastuhu, 1994. Dinamika Sistem Pesantren, Jakarta: Sen INIS.

Masyhud, Sulthon dkk. Manajemen Pondok Pesantren, (Jakarta: Diva Pustaka, 2003), h. 15.

Nita Siti Mudawamah, "Perilaku Pengguna Internet...", BIBLIOTIKA: Jurnal Kajian Perpustakaan dan Informasi Volume 4 Nomor 1, 2020, http://journal2.um.ac.id/index.php/bibliotika.

Nizar, Samsul. et.al. 2013. Sejarah Sosial dan Dinamika Intelektual Pendidikan Islam di Nusantara, (Jakarta: Kencana Prenada Media Group.

Qudsy, Saifuddin Zuhri 2019. "Pesantren Online: Pergeseran Otoritas Keagamaan di Dunia Maya", dalam Living Islam: Journal of Islamic Discourses, Volume II Nomor 2, November

Turmudi, Endang. 2004. Perselingkuhan Kiai dan Kekuasaan, Yogyakarta: LkiS, 
Hatta Fakhrurrozo, Pesantren...

Wahjoetomo, 1997. Perguruan Tinggi Pesantren, (Jakarta: Gema Insani Press. 